Meta

Journal des traducteurs

Translators' Journal

\title{
Analysis of Charterparty Agreements from Textual Genre and Translation Points of View
}

\section{Maribel Del Pozo Triviño}

Volume 59, numéro 1, avril 2014

URI : https://id.erudit.org/iderudit/1026475ar

DOI : https://doi.org/10.7202/1026475ar

Aller au sommaire du numéro

\section{Éditeur(s)}

Les Presses de l’Université de Montréal

ISSN

0026-0452 (imprimé)

1492-1421 (numérique)

Découvrir la revue

Citer cet article

Del Pozo Triviño, M. (2014). Analysis of Charterparty Agreements from Textual Genre and Translation Points of View. Meta, 59(1), 160-175.

https://doi.org/10.7202/1026475ar

\section{Résumé de l'article}

De nos jours, le transport maritime représente un trafic et des chiffres considérables dans le monde entier. Il en découle une importante activité commerciale de nature multiculturelle et multilingue, pour laquelle la plupart des transactions s'effectuent en anglais. Il n'est donc pas surprenant que l'activité maritime génère de gros volumes de travail en traduction, particulièrement depuis l'anglais vers d'autres langues. L'un des documents maritimes qui suscitent le plus de demandes en traduction est la charte-partie, un contrat d'affrètement qui permet au propriétaire d'un navire de louer ce dernier à une autre partie moyennant une somme convenue. Le présent article se concentre sur l'analyse des contrats de charte-partie d'un point de vue traductionnel. La méthode d'analyse, qui se base sur le concept de genre textuel, sera tout d'abord examinée, puis suivra une analyse détaillée du contrat de charte-partie.
Tous droits réservés @ Les Presses de l’Université de Montréal, 2014
Ce document est protégé par la loi sur le droit d'auteur. L'utilisation des services d'Érudit (y compris la reproduction) est assujettie à sa politique d'utilisation que vous pouvez consulter en ligne.

https://apropos.erudit.org/fr/usagers/politique-dutilisation/ 


\title{
Analysis of Charterparty Agreements from Textual Genre and Translation Points of View
}

\author{
MARIBEL DEL POZO TRIVIÑO \\ Universidade de Vigo, Vigo, Spain \\ mdelpozo@uvigo.es
}

\section{RÉSUMÉ}

De nos jours, le transport maritime représente un trafic et des chiffres considérables dans le monde entier. Il en découle une importante activité commerciale de nature multiculturelle et multilingue, pour laquelle la plupart des transactions s'effectuent en anglais. II n'est donc pas surprenant que l'activité maritime génère de gros volumes de travail en traduction, particulièrement depuis l'anglais vers d'autres langues. L'un des documents maritimes qui suscitent le plus de demandes en traduction est la chartepartie, un contrat d'affrètement qui permet au propriétaire d'un navire de louer ce dernier à une autre partie moyennant une somme convenue. Le présent article se concentre sur l'analyse des contrats de charte-partie d'un point de vue traductionnel. La méthode d'analyse, qui se base sur le concept de genre textuel, sera tout d'abord examinée, puis suivra une analyse détaillée du contrat de charte-partie.

\begin{abstract}
Maritime transportation in the world today accounts for huge turnover figures and it provides sizeable commercial activity of a multicultural and multilingual nature. Most of these transactions are carried out in English, and consequently, it is not surprising that such activity generates a large amount of translation work, especially from English into other languages. One of the maritime legal documents that frequently requires translation is the Charterparty, an agreement that enables a ship-owner to charter his vessel to another party for a certain consideration. This paper focuses on the analysis of the Charterparty Agreement from a translation point of view. First, we will describe the analysis method, which is based on the concept of textual genre, and then we will proceed to a detailed analysis of the Charterparty Agreement.
\end{abstract}

\section{MOTS-CLÉS/KEYWORDS}

genre, sous-genre, transgenre, contrat de charte-partie, traduction juridique genre, subgenre, transgenre, Charterparty Agreement, legal translation

\section{Introduction}

The objective of this paper is to provide translators of Charterparty Agreements with an in-depth knowledge of this much-specialized genre, in order to help them make their translation process more efficient. This paper has two parts: the first one, entitled Description of the analysis framework based on the concept of genre, defines the concept of genre and the methodological guidelines used for analysing Charterparty Agreements, and the second one, entitled Analysis of the Charterparty Agreement genre, applies the said methodological guidelines to analyse these documents.

This paper does not fully revise genre theory, but rather presents the main aspects that are applicable to the analysis of the Charterparty Agreement genre. The analysis 
carried out herein covers context and macrostructure in-depth, but does not fully cover certain microstructural aspects that are also important for translation because they fall outside the scope of this paper.

\section{Description of the analysis framework based on the concept of genre}

According to Montalt Resurreció, Ezpeleta Piorno and García Izquierdo,

[ $t$ ] he latest tendencies in Translation Studies highlight the need to diversify the way translation is analysed by considering not only the variables that are traditionally addressed by the theoretical models (i.e. meaning, equivalence, skopos, and so forth), but also the multifaceted concepts that can help us to understand the mechanisms at play in the production of human and social interaction, of which translation is an example. One of these concepts, which is proving to be a valuable aid in the analysis, teaching and practice of translation, is the concept of textual genre. (Montalt Resurreció, Ezpeleta Piorno and García Izquierdo 2008: 4)

Genre theory dates back to the times of ancient Greek literature. It has evolved through centuries and has been applied to the different fields of knowledge and research. The notion of textual genre was introduced in Translation Studies after the 1970s and achieved wide acceptance through the work of Reiss and Vermeer (1984) and Hatim and Mason (1990), who followed systemic functionalists such as Martin (1984) and audiovisual communication scholars such as Kress (1985). The concept furthermore acquired great recognition in Language for Specific Purposes (LSP) (Bhatia 2000; Swales 1990). All the aforementioned scholars have defined genre from formal, socio-cultural and cognitive perspectives.

Based on this wholesome concept of genre, the GENTT' ${ }^{1}$ (Géneros Textuales para la Traducción - Textual Genres for Translation) research group in Spain developed a theoretical and conceptual framework to study genres from specialized communication fields (mainly legal, medical and technical) (Borja Albi, García Izquierdo et al. 2009). The group designed a set of methodological guidelines for analyzing specialized documents in order to break them down into their constituent characteristics. Such guidelines are flexible, dynamic and can generally be used for analyzing all types of specialized and conventionalized texts. They essentially take into account different aspects in specialized fields that are usually alien and unknown to most translators. For instance, if we are not familiar with the maritime sector, then we would obviously not know the meaning of terms such as Sea Protest or how to draft a Vessel Charterparty Agreement or know which elements are essential to a Bill of Lading for it to have legal effect. All this information is essential, and therefore, translators must not only have a command of both source and target languages, but also need to have extra-linguistic knowledge of the documents they intend to translate in order to be successful in their communicative mediation task. Examples of specialized genres where GENTT members have applied the research methodology successfully include patents (Aragonés Lumeras 2009), medical reports (Ezpeleta Piorno 2008) and free software licences (Gandía García 2011), to mention just a few.

The analysis framework proposed in this paper for studying the Charterparty Agreement genre follows the guidelines proposed by GENTT. It can be described as a wide framework that takes into account not only formal and content factors, such as macro-structure and legal background, but also linguistic and extra-linguistic 
ones, such as the use of stereotyped language and specialized terminology. Furthermore, it is deliberately eclectic since it contains concepts not only from Systemic Functional Linguistics, LSP and Socio-communicative Studies, but also from genre theory applied to Translation Studies. Concepts, such as genre, subgenre, communicative situation, formal and contrastive issues and relationship with other genres form the skeleton of the analysis tool used. The following table presents the basic structure of the analysis framework for specialized genres. A detailed explanation of each element of the table is subsequently provided and then applied to the analysis of the Charterparty Agreement.

TABLE 1

Levels of analysis for specialised genres ${ }^{2}$

\begin{tabular}{|l|}
\hline Genre \\
\hline Subgenres \\
\hline Communicative situation \\
\hline Formal and contrastive issues \\
\hline Relationship with other genres \\
\hline
\end{tabular}

\subsection{Genre}

Genre theory explains the manner in which the communicative events produced by a specialized linguistic community are structured (Swales 1990). A genre can thus be described as a highly structured communicative written or oral event. Based on Swales' works on genre analysis $(1981 ; 1986 ; 1990)$, Bhatia proceeded to define genre as

[...] a recognisable communicative event characterised by a set of communicative purpose(s) identified and mutually understood by the members of the professional or academic community in which it regularly occurs. Most often it is highly structured and conventionalised with constraints on allowable contributions in terms of their intent, positioning, form and functional value. These constraints, however, are often exploited by expert members of the discourse community to achieve private intentions within the framework of socially recognised purpose(s). (Bhatia 1993: 13)

Following Bhatia's description, the concept of genre used in the present work not only includes formal and socio-cultural aspects of texts, but also cognitive aspects, amongst which worth mentioning is the intention of the participants in the communication act.

Genres are firstly defined by the communication purpose that they try to fulfil. This is what determines the remainder of the characteristics and the one that permits differentiation between genres. (Ezpeleta Piorno 2008: 431 $1^{3}$, translated by the author)

Another issue worth highlighting, from a translation point of view, is that classification into different textual genres sometimes coincides in the two linguistic systems (source and target), but no perfect equivalence in both systems is observed at times. Generally speaking, the more globalized the systems, the more equivalent genres we can find in such systems. Maritime activity is truly international, and therefore, many of the genres used in this field, such as Charterparty, Bill of Lading, Marine Insurance, Sea Protest, etc. are universally used even though translators need to take into account the national context in which they emerged when translating 
them. The frequent international use of such genres means we can find equivalent genres spread out over different countries and continents.

\subsection{Subgenre}

There are times when genres give rise to subgenres. This happens mainly when they respond to variations or specifications of the communications purpose (Ezpeleta Piorno 2008). The said communications purpose variations or specifications of genres are in turn related to the end result, i.e., the communication act of the participants.

As is the case with genres, subgenres within a specific legal context may sometimes not coincide with subgenres of the legal system of the target language and this is the reason why specificities of subgenres need to be taken into account when translating them. In the legal context, this mainly happens with genres that are less standardized and less uniform. This is because such genres and subgenres are part of a specific legal system and have not been subjected to the globalization process. For instance, the subgenres of Naval Mortgage are quite different in different legal systems because the said genre has not undergone a strong standardization process. However, the subgenres of the Charterparty Agreement are practically the same everywhere since they are always derived from international models.

Knowledge of the different subgenres is therefore important when translating such documents since many formal and communicative aspects of the original text will be determined by the subgenre to which they belong. For example, in the case of the Charterparty Agreement, if the original text is called BALTIME or LINERTIME we know that we are dealing with a Time Charterparty, i.e., an agreement to charter the vessel for a certain amount of time. However, if the original document is called GENCON, we know that the charter would be for a number of trips rather than for an amount of times, as will be explained in more detail in section 3.2. hereunder.

\subsection{Communicative Situation}

We can only talk about genre whenever members of professional and academic bodies accept and recognize a particular text or document as a genre. At this level of analysis, we need to turn to Linguistics concepts to explain the communicative situation of a specific genre. These concepts refer to register (field, tenor and mode) and user (sender, receiver, idiolects, etc.):

Genres always emerge in specific communicative situations, i.e., they include a set of elements that are directly related to the emission and reception of the message. The categories encompassed within the communicative dimension of the context are: sender, receiver, field, mode and tone or tenor (Gamero Pérez 2001: 554; translated by the author).

Maritime legal documents are usually written documents, and their tenor is formal. The field is specialized, and moreover, we are talking about documents that are drafted by specialists and are usually destined to specialists: maritime agents, lawyers, etc. and not for the general public.

As stated earlier, my conception of the translation activity is framed within a global approach that takes into account not only the document's field of specialization, tenor and mode of presentation, but also the fact that such activity is carried 
out within a specific socio-cultural context that strongly affects the nature of the same. Therefore, when we approach a text, we ought to also analyze the socio-cultural context in which each of the analyzed genres fits. In this line, Gamero Pérez outlines factors that must be taken into account when considering the communicative situation of a specific genre, and therefore, its socio-cultural context:

With respect to translation, one should bear in mind that socio-cultural contexts: (a) determine genre conventions in each culture, (b) perform an essential function when creating new genres since they respond to specific communication needs that may be common or not in the different cultures, and (c) determine the guidelines in genre evolution since they adapt to changes produced in the culture in which they are used. (Gamero Pérez 2001: 575; translated by the author)

\subsection{Formal and Contrastive Issues}

Genres are structured and conventionalized communication actions. Cuddon describes convention as:

[...] a device, principle, procedure or form which is generally accepted and through which there is an agreement between the writer and his readers which subjects him to various freedoms and restrictions (Cuddon 1992: 192).

Characteristic genre conventions are the formal traits sanctioned by the user community to the detriment of others that are linguistically acceptable, but do not fit into the agreed patterns (Ezpeleta Piorno 2008: 432). Formal aspects refer to directly observable elements of the communicative act, namely: structural characteristics and intra-textual aspects (amongst which are discourse level, lexicon, level of terminological density, non-verbal graphic elements, etc.).

This level of analysis tackles issues of a formal nature that characterize a specific genre. These can be divided into:

a) macrostructure-related issues, such as document size and layout, its spread into paragraphs, clauses, etc.;

b) microstructure-related issues, such as syntax, aspects related to cohesion and coherence, typography, terminology and phraseology, etc.

It is not uncommon to find that genres present a macrostructure that changes according to the cultural context in which they arise. Likewise, when documents belong to a globalized international system, it is not surprising to find a uniform format in certain genres that is independent of the cultural context in which they lie. For documents generated within the maritime legal activity, there is a strong trend towards document homogenization, and therefore, the macrostructure of such documents tends to be quite similar from one to another, if not identical. For instance, in the case of Charterparty Agreements, as discussed in detail in section 3.4., the commonly used templates are those prepared by the BIMCO (Baltic and International Maritime Council), the largest international shipping association. These templates consist of two parts: Part I consists of numbered boxes with spaces where one fills in information on the vessel and the parties, and Part II holds the actual clauses of the agreement.

When analyzing the macrostructure of a particular genre, we need to bear in mind that translation is an activity that always involves a minimum of two languages 
and cultural systems. Therefore, to know the elements pertaining to each of them, it is often useful to compare the genre macrostructure of the two systems before proceeding to translate. Such comparative analysis acquires higher relevance in genres where macrostructures differ greatly in the two systems. Relevance is low when the genres are practically the same in both systems, as is the case with Charterparty Agreements analyzed herein.

As far as macrostructure is concerned, translators are often faced with a dilemma whenever the macrostructure of a particular genre is different in both the target and the source language. In such cases, there arises the perpetual issue of whether to adapt the text or not. The following are the options available:

a) respect the macrostructure of the source text and reproduce it in the target text;

b) adapt the macrostructure of the original text to the generic macrostructure of the target text;

c) adopt an intermediate solution that produces a hybrid.

I believe that, in the case of legal translation, it is important to respect the macrostructure of the original text, since such documents are frequently used in multilingual meetings and negotiations, and therefore, all participants should have the same layout, as much as possible. This is not the case with other genres, such as, for example, business letters, for which it is essential to adapt the macrostructure of the original genre to the macrostructure of the target genre.

As far as microstructural issues are concerned, these would include the analysis of language-related aspects, such as syntax, phraseology, terminology, etc. which characterize a specific text genre. The analysis of the Charterparty Agreement presented herein does not carry out a systematic analysis of microstructural aspects. However, many references thereto are included throughout the paper.

Another important aspect to analyze in this section, in the case of legal genres, is the fact that many formal issues are determined by the legal context in which they are inserted, and therefore, by the legal system governing the same. Thus, legislative aspects that affect each of the genres in the respective legal systems should also be included at this analysis level when reviewing formal and contrastive aspects, although it could be argued that the legal context is an aspect related to the communicative situation.

If we take the communicative situation and the formal and contrastive issues into account when translating a particular genre, then it leads us to the concept of transgenre, a term first used in Spanish tradition for analyzing genres by Monzó (2002), one of the members of the GENTT research group. A transgenre arises when a genre belonging to a specific sociocultural and linguistic context gets transferred to a new one. The translational process creates a sole hybrid with unique characteristics that contains elements from the source context's para-culture as well as elements from the target context's.

\subsection{Relationship with other Genres}

When analyzing genres, it is important to establish the relationship that a particular genre has with others. In this line, Bazerman states that, from a legal point of view, there exists what he calls "systems of genre" which he describes as "...interrelated genres that interact with each other in specific settings" (Bazerman 1994: 97). 
According to Bazerman, a good amount of genres are interdependent, and he cites the example of patents:

Only a limited range of genres may appropriately follow upon another in particular settings, because the success conditions of the actions of each require various states of affairs to exist. That is, a patent may not be issued unless there is an application. An infringement complaint cannot be filed unless there is a valid patent. An affidavit about the events in a laboratory on a certain date will not be sworn unless a challenge to the patent is filed. (Bazerman 1994: 98)

In the case of documents generated as part of maritime activity, there is a clear genre system within this specialization. This system in turn has a number of subsystems. In fact, law firms who work for shipbuilders or ship-owner companies have created their own division into sub-systems and often request translation of all interrelated documents (linked genres within a specific project). The Purchase and Sale Agreement of a new vessel can be cited as an example. Such an operation cannot be carried out without reference being made to the Shipbuilding Contract that governs construction of the vessel. The buyer of the vessel must provide approval to the construction of the vessel by the shipyard prior to signing the Vessel Purchase and Sale Agreement. In like manner, and at the time of purchase, the shipyard must provide documents related to the seaworthiness of the vessel built, as well as registration documents, etc. Other documents issued at the time of purchase are the Bill of Sale and the Protocol of Delivery and Acceptance. All of the above are part of the one transaction that requires a well-defined documentary system, or what Bazerman calls, "systems of genre."

\section{Analysis of the Charterparty Agreement Genre}

An in-depth analysis of the Charterparty Agreement from a translation point of view is carried out herein according to the framework presented in earlier paragraphs. The objective is to determine the characteristics of the genre called Charterparty Agreement in order to provide translators with a first approximation of the same, which in turn would ensure a better translation into the target language.

Original English Charterparty Agreements are analyzed irrespective of the target language into which they may be translated. However, examples derived from translation into Spanish are used whenever contrastive issues are mentioned.

\subsection{The Charterparty Genre}

A Charterparty is an agreement that permits a ship-owner to charter his vessel to another party for a certain consideration. It is therefore a conventionalized document that fulfils a specific communicative intention. According to Alcaraz Varó and Hughes (1997/2006: 78) ${ }^{6}$ the word Charterparty is derived from the Latin term charta partita, which was so-called because the document was split into two parts after signature. Each party held on to one part of the contract as proof. This genre is usually referred to as póliza de fletamento in Spanish. However, there are other translations of the term being used, which include: carta de fletamento, carta de partida, contrata de fletamento, contrato de alquiler de un barco, contrato de fletamento, contrato de fletamiento, fletamiento, póliza de fletamiento, póliza de fletes, etc. 


\subsection{Subgenres of the Charterparty Agreement}

As explained in section 2.2., subgenres of a particular genre are generated whenever there are variations or specifications of the communicative purposes. The genre Charterparty is generally defined as an agreement for the hire of all or part of a ship, for a specified voyage or period of time. The variations or specifications of such general purposes generate a number of subgenres that are worth mentioning here, due to their importance in goods transportation by sea. The following are the most important ones.

\subsubsection{Time-Charter (póliza de fletamento por tiempo)}

This is a contract wherein a vessel is placed at the disposal of a charterer, at a price called charter fee, to carry out trips/voyages for the charterer during a certain time period. As Del Pozo Triviño and Padín Romero explain, in Time-Charters,

[c]ommercial management of the vessel is transferred to the charterer through this contract, but the ship-owner maintains control and nautical management of the vessel. This contract is characterized by a sharing of the expenses and risks by the parties to the contract: the ship-owner continues to bear expenses related to the vessel's seaworthiness, while the charterer takes on the commercial risks and expenses. This type of contract is very common in practice. (Del Pozo Triviño and Padín Romero 2005: 8097; translated by the author)

The absence of specific legislation to govern the nature of the contract has given rise to the presence of a number of Time-Charter models and types in the market, notable amongst which are: BALTIME, NYPE, LINERTIME, and other models that have been created by oil companies, such as STBTIME, SHELLTIME 4, etc.

\subsubsection{Voyage Charter (póliza de fletamento por viaje)}

This is a typical historical standard agreement that is entered into when the charterer wants to hire the entire cargo capacity of a vessel for a certain voyage. No transfer of commercial management or vessel nautical management takes place in this type of contract. The ship-owner keeps full control of both and only rents the vessel's transportation capacity to the charterer for a specific voyage.

There are a number of models of Voyage Charter Agreements, amongst which we can highlight GENCON, the model that is the most commonly used. Other Voyage Charter models include GRAINVOY, NORGRAIN, SYNACOMEX, CORE 7, EXXONVOY and SHELLVOY.

There are notable differences between the Time-Charter and the Voyage Charter, i.e., under the Time-Charter, the commercial management of the vessel is transferred from the ship-owner to the charterer, while this does not take place under the Voyage Charter. The result is that in Time-Charters, the captain becomes subordinated to orders from the charterer for all decisions concerning the trip.

\subsubsection{Demise/Bareboat Charter (fletamento a casco desnudo)}

As explained by Alcaraz Varó and Hughes (1997/2006: 79; see note 6), in this type of charter, the ship-owner hires the vessel to the charterer excluding crew and fuel. The charterer takes responsibility for the crewing and maintenance of the ship during 
the time of the charter, assuming the legal responsibilities of the owner, and is known as a "disponent owner."

Other Spanish translations usually found for the term are: fletamento sin tripulación and fletamento con cesión de la gestión náutica.

\subsubsection{Others}

Besides the aforementioned three types of agreements, there are other agreements that coexist and are half-way between Time-Charter and Voyage Charter, such as:

- Consecutive Voyage Charter (fletamento por viajes consecutivos). This is one in which the vessel is chartered for a set number of continuous voyages or for as many voyages as may be completed within a certain period of time.

- Volume Contract or Tonnage Agreement (contrato de volumen or contrato por volumen). In this case, the vessel is chartered for as many voyages as may be required to transport a certain amount of goods.

- Round Voyage Charter (viaje redondo, fletamento de viaje redondo or fletamiento por viaje redondo). Here, the vessel is chartered for one voyage, but on a TimeCharter basis, i.e., chartered for the time taken to complete a certain voyage.

- Slot Charter (fletamento de slots). This is one in which certain slots, that is, spaces of fixed dimensions that accommodate a standard container, are chartered instead of chartering the entire vessel.

\subsection{Communicative Situation of the Charterparty Agreement}

As explained in section 2.3., this section will now discuss aspects related to the context and the communicative situation of Charterparty Agreements when they are relevant for the translation process.

The Charterparty is a consented agreement, and therefore, a written format is not needed for it to exist and be efficient. Hence, a written format is only needed for proof purposes. However, it is common, in maritime traffic, to formalize maritime transport contracts in writing. This is initially done through entries made in the ship's logbook, in the onboard Bill of Lading, and much later in the agreement called Charterparty. To that end, Gabaldón García and Ruiz Soroa explain:

The contract is not initially subject to the written format (except when applied by analogy to section 652 of the civil code that refers to freight), but in practice, it is presented in written format because of the important consequences inherent in the same. (Gabaldón García and Ruiz Soroa 2002: $404^{8}$, translated by the author)

There are several agents involved when establishing a Charterparty. Gabaldón García and Ruiz Soroa (2002) classify them into personal elements and property elements as follows:

- The personal elements include the master or captain (capitán), shipper (cargador), agent, ship's agent or shipping agent (consignatario de buques), broker or shipbroker (corredor or corredor de fletes), consignee (destinatario or receptor de las mercancías), charterer (fletador), ship's husband (naviero), owner or ship-owner (armador) and carrier (porteador or transportista).

- The property elements include vessel (buque), cargo (cargamento) and freight (flete).

The vessel owner (the sender) is usually the person who drafts the Charterparty Agreement and sends it to the charterer (the receiver). The main function of the 
Agreement is to establish the charter conditions. Once the charterer receives the document, he or she includes his or her suggestions by deleting and/or adding text. It is important to reflect such deletion and additions (if any) when translating, especially if the agreement is being translated during the negotiation phase.

\subsection{Formal and Contrastive Issues related to the Charterparty Agreement}

As already explained in section 1.4., I have deliberately chosen to deal with the legal context in this section rather than in the earlier one, even though it could be argued that issues related to the legal context in which a particular genre emerges is an important aspect of its communicative situation. This is because many formal features of genres are determined by the legal context in which they emerge.

This section therefore begins by providing a description of the legal contexts in which Charterparty Agreements have arisen. According to Del Pozo Triviño and Padín Romero (2005: 814-815), there are few currently applicable international legal norms for any type of maritime transportation, and the only relatively satisfactory method for regulating maritime transport is the so-called Bill of Lading. ${ }^{9}$ The authors explain that the basic historical milestones in the evolution of uniform rules were the following:

- the Hague Rules of 1922;

- the 1924 Brussels Convention, also known as the International Convention for the Unification of Certain Rules of Law relating to Bills of Lading;

- the 1968 Brussels Protocol: this protocol is also known as the Hague-Visby Rules and is an update of the Brussels Convention;

- the 1978 Hamburg Rules.

The Charterparty Agreement is not subject to any uniform regulation, and therefore, the only maritime transportation uniform law is the one applicable to the Bill of Lading. Rodríguez Gayán (1999: 46-56) states that attempts made to regulate the Charterparty Agreement at international level were found to have very little impact. Therefore, the U.K. law is nowadays widely applicable in private maritime transportation even though the actors (lawyers and people involved) may not always be bound by the U.K. legal system. This is due to two main reasons. Firstly, because most maritime navigation disputes are resolved with recourse to the arbitrage clause, according to U.K. law, and take place in London. And secondly, because even if the controversy were taken to a different court in another country, such court would find it quite difficult to understand the written agreements without prior knowledge of the Common Law rules that determined the inclusion or modification of certain clauses.

On the subject of the U.K. maritime law, the 1894 Merchant Shipping Act contains most of the private and public Navigation Statutory Law. This basic written law was modified on many occasions by several Merchant Shipping Acts and other special Acts, such as the 1992 Carriage of Goods by Sea Act, whose intention was to introduce international maritime conventions into the same. Besides this statutory (written) law, also present is the Case Law, which is created by judicial decisions, and it continues to have its traditional and usual importance in the field. The same happens in U.S. legislation, which is partly Statute Law and partly Case Law, i.e., rulings imposed by judges and courts. 
Generally speaking, Charterparties in the U.K. are regulated by rules that Case Law established from cases that it handled, i.e., there is no statutory regulation as such. There is only one legal regulation in the field of transportation, namely the Bill of Lading, by virtue of the 1924 Brussels Convention.

With regard to the Spanish context, Del Pozo Triviño and Padín Romero (2005: 816) explain that such type of transportation in Spain is internally subject to dual treatment, namely the U.K. law and the Spanish law. Thus Charterparties are subject to both jurisdictions because such agreements originated in the U.K. Common Law. The authors explain that many such agreements are drafted as a list of exceptions and exemptions of the Case Law principles established in the U.K., rather than as a full-blown contract on its own.

Therefore, when interpreting and translating such model Charterparties into Spanish, translators should bear in mind that such models evolved within the U.K. legal system, thanks to the maritime hegemony of the said country. Therefore, Charterparties were essentially drafted according to the rules created by English Case Law, these being excessively casuistic and detailed. ${ }^{10}$ This leads us to the fact that one cannot fully understand the several Charterparty models without taking into account the legal framework in which they were created. Hence, the interpretations granted by English Case Law to certain clauses should be accepted even in other unrelated legal fields not only because U.K. law is applicable to the specific case, but also because it is the usual way to interpret such clauses.

The influence of the U.K. law thus becomes evident not only when drafting and approving models, but also when introducing modifications or changes in the same. Charterparties sometimes contain concepts and expressions that are strange and even indecipherable for some continental jurists and furthermore contain solutions that are unfair and biased towards the shipping companies.

Del Pozo Triviño and Padín Romero (2005) furthermore explain that, in Spain, Charterparty is governed by the Spanish Civil Code, which only regulates Voyage Charter, but not Time-Charter. The 1924, 1968 and 1979 Brussels Conventions were incorporated into the internal Spanish norms through a special Act dated December $22^{\text {nd }} 1949$, and usually known as the Maritime Goods Transportation Act (Ley de Transporte de Mercancías por Mar - L.T.M.). For issues not regulated by the LTM, one needs to turn to the rules of the Spanish Code of Commerce. Mention must also be made that the Brussels Convention cannot be applied if goods are transported between Spanish ports with a Bill of Lading, because such transportation is ruled by the precepts of the Code of Commerce for freight.

However, Del Pozo Triviño and Padín Romero explain that the true regulation of such agreements lies within the Charterparties themselves, and to that end state that:

Agreements have existed since immemorial times and were operated based on general agreement terms. Such agreements were drafted, corrected and modified for each voyage by the interested parties by deleting, adding, and incorporating specific clauses on a case-by-case basis. This was done frequently and without much precision, thereby generating agreements that were ambiguous and confusing. A basic rule of thumb on the subject is that any clause later added to the printed Charterparty document reflects the direct will of the parties and therefore must prevail over the original clauses contained therein. Generally speaking, all cancellations that appear in the document must be translated and displayed as cancellations in the final document accepted by both 
parties. This is so done so as to reflect the changes made in the original document, and consequently, the objectives sought after by the signatories. (Del Pozo Triviño and Padín Romero 2005: $818^{11}$; translated by the author)

Now that the rules applicable to Charterparties within the sociocultural context in which they arise have been explained, we can proceed to perform an analysis of the genre macrostructure.

The Charterparty Agreement ${ }^{12}$ is made up of two parts: the first contains boxes for specifying the property elements and personal elements, while the second contains clauses that have been freely drawn up and introduced. ${ }^{13}$

Most maritime legal forms contain general contracting terms with an international scope since they are normally used worldwide. This is the case with Charterparties, Bills of Lading and other documents from international organisations such as the BIMCO (Baltic and International Maritime Council), INTERTANKO (Independent Tanker Owners and Operators of Oil and Chemical Tankers), the INTERCARGO (International Association of Dry Cargo Ship-owners) and the ASBA (Association of Ship Brokers and Agents). The so-called private agreements are limited in scope when compared to the Charterparty general terms prepared by large multinational oil corporations for chartering oil tankers. The following table alphabetically outlines some of the main clauses included in the BIMCO forms, for illustration purposes.

TABLE 2

The main clauses of BIMCO charterparties

\begin{tabular}{|l|}
\hline Arbitration and Law \\
\hline Brokerage \\
\hline Bunkers \\
\hline Cancelling Clause \\
\hline Charterer's Obligations \\
\hline Demurrage \\
\hline Deviation \\
\hline Freight \\
\hline General Average \\
\hline General Ice Clause \\
\hline General Strike Clause \\
\hline Laytime \\
\hline Lien Clause \\
\hline Loading-Discharging \\
\hline New Jason Clause and Both-to-Blame Collision Clause \\
\hline Owner's Obligations \\
\hline Period/Port/Time of Delivery \\
\hline Recitals \\
\hline Re-delivery \\
\hline Sublet \\
\hline War Risks “Voywar 1993”/“Conwartime 1993” \\
\hline
\end{tabular}

As far as the macrostructure of Spanish Charterparties is concerned, according to article 652 of its Code of Commerce, the póliza de fletamento must not only contain the clauses agreed upon by the parties, but should also contain the following 
information: "clase, nombre, porte y pabellón del buque" [vessel class, name, tonnage and flag].

From a translation point of view, and with respect to the dilemma referred to in section 1.4., as to whether to adapt the macrostructure of the source genre to that of the target genre, there is no dilemma in the case of Charterparty Agreements since, as already stated above, they are usually standard forms.

However, I believe a certain adaptation is needed at the microstructural level. For instance, changes should be made with respect to the use of typical contract phraseology (hereinafter referred to as "the Vessel" - en lo sucesivo "el buque"), capital letters (Owners - armadores, Charterers - fletadores), passive voice, etc.

Use of terminology should also be appropriate to the maritime context, for example, the word tonnage could be translated into Spanish as tonelaje and arqueo, however, the latter is the most commonly used term in this field. The same criteria applies to the word flag, which in general contexts is translated as bandera, but the preferred term in the maritime context is pabellón.

\subsection{Relationship of the Charterparty Agreement with other Genres}

The Charterparty is closely linked to the Bill of Lading ${ }^{14}(\mathrm{BL}-$ sometimes referred to as $\mathrm{BOL}$ or $\mathrm{B} / \mathrm{L}$ ), which is a document issued by a carrier to a shipper acknowledging that certain goods have been received on board as cargo for conveyance to a named place for delivery to a specific consignee. The term derives from the verb to lade, which means to load cargo onto a ship or other form of transportation. The translation into Spanish is conocimiento de embarque.

As explained in section 3.1., a Charterparty is an agreement in which a shipowner lets or hires out his ship(s) to another party, called the charterer, for carriage of goods by sea for a certain consideration known as hire. The Charterparty would be either a Time-Charter, Voyage Charter or Demise Charter, and the charterer may charter the ship for the purpose of carrying his goods wholly or partly and/or to enter into a subcontract of carriage with other shippers who would provide all or part of the goods shipment, or to employ the ship as a general ship. A Bill of Lading is normally issued in all cases whenever goods are loaded or shipped.

We can therefore conclude that Charterparty Agreements are closely related to Bills of Lading. However, depending on the activity for which the vessels are chartered, they can also be linked to other genres, such as Marine Insurance and other documents related to loading, transportation, unloading and delivery of goods, such as the Single Administrative Document (SAD) (documento único administrativo [DUA]) and the Cargo Manifest (manifiesto de carga), just to mention a few.

\section{Conclusions}

Communication is a human activity that responds to certain motivations, where the type of message depends on the communicative intentions and the function of the message. Such pragmatic situations in developed societies give rise to conventional textual structures called textual genres.

This characteristic is especially relevant in the legal field, where we find that texts possess fixed structures that lead to rigid and repetitive models. According to Borja Albi, 
[a]ll of that produces a selection of content, a way of putting forward facts, which unequivocally confers rhetoric and a perception of the world to each legal text. If we add a clear communicative objective or a specific legal function to this drafting of text, the result obtained is the concept of 'legal genre.' (Borja Albi 2007: 144'15, translated by the author)

Many authors defend the use of the genre concept to study the several areas in the legal field. For example, Bhatia highlights the importance of the concept of genre in learning:

In other words, learners need to develop the understanding of code, the acquisition of genre knowledge associated with the specialist culture, sensitivity to cognitive structuring of specialist genres and then, and only then, can they hope to exploit generic knowledge of a repertoire of specialist genres by becoming informed users of the discourse of their chosen field. (Bhatia 1997: 134)

The main conclusion derived from this study is that knowledge of genres linked to the legal field, and more specifically to maritime activity, can be a valuable tool for beginner and professional translators when working in such specialized settings. As pointed out by Wen (2004), genre analysis helps make translators aware that different professional genres may require different steps when restructuring the source text.

Another conclusion drawn both from my research and my work experience is that the analysis framework described in section 2, based on the research guidelines developed by GENTT, is of great help when analyzing the Charterparty Agreement genre. However, I am also aware that a more detailed analysis could have been performed if the analysis framework had been widened to include contrastive issues related to microstructure, such as syntax, phraseology and terminology. I intend to perfect this tool in future works so that it can be of better use to analyze legal genres that pose challenges to translation professionals.

I hope that the analysis of the Charterparty Agreement carried out in this paper will bring further knowledge about this genre by providing not only textual information, but also information on professional practices and conventions related to its socio-communicative context. Such knowledge would surely help translators improve their professional performance.

\section{NOTES}

1. GENTT. Géneros textuales para la traducción. Visited on 28 July 2011, <http:www.gentt.uji. $\mathrm{es} / \mathrm{q}=\mathrm{es}>$.

2. This table, based on GENTT research guidelines, was adapted by the author in her $\mathrm{PhD}$ thesis to analyze maritime documents. This analysis framework has been furthermore applied in her ongoing research (Del Pozo Triviño 2007; 2011).

3. "Los géneros se definen en primer lugar por el propósito comunicativo que pretenden cumplir. Éste es el que determina el resto de sus características y el que permite diferenciar unos géneros de otros." (Ezpeleta Piorno 2008: 431)

4. "El género se inscribe siempre en una situación comunicativa determinada, es decir, incluye una serie de elementos relacionados de forma directa con la producción y recepción del mensaje. Las categorías enmarcadas dentro de la dimensión comunicativa del contexto son: emisor, receptor, campo, modo y tono o tenor." (Gamero Pérez 2001: 55)

5. "En relación con la traducción, hemos de tener en cuenta que los contextos socioculturales: (a) determinan las convenciones propias de los géneros en cada cultura; (b) desempeñan una función primordial a la hora de crear nuevos géneros ya que estos responden a necesidades comunicativas concretas que pueden ser comunes o no a diferentes culturas; y (c) marcan la pauta en la evolución 
de los géneros, puesto que éstos se adaptan a los cambios que se producen en la cultura en la que se usan." (Gamero Pérez 2001: 57)

6. Alcaraz Varó, Enrique and Hughes, Brian (1997/2006): Diccionario de términos jurídicos. Inglésespañol. Barcelona: Ariel.

7. "Por medio de este contrato se cede la gestión comercial del buque al fletador, conservando el naviero el control y la gestión náutica del mismo. Característico de este contrato es el reparto de gastos y riesgos entre las partes: el naviero continúa con los gastos derivados del mantenimiento navegacional del bueque, mientras que el fletador asume los gastos y riesgos de su explotación comercial. Este contrato se utiliza profusamente en la práctica." (Del Pozo Triviño y Padín Romero 2005: 809)

8. "El contrato no está en principio sujeto a forma escrita (salvo que se entienda aplicable por analogía al art. 652 del C. de c., referente al fletamento) pero en la práctica, dadas las importantes consecuencias que conlleva, se reduce siempre a escrito." (Gabaldón García and Ruiz Soroa 2002: 404)

9. Also see Rodríguez Gayán (1999: 123-135).

10. For a study of the casuistic nature of Common Law versus Civil Law, see Ferran Larraz (2011).

11. "Existen pólizas tipo desde antiguo, que funcionan a manera de condiciones generales de contratación. Estos modelos de pólizas son completados, corregidos o modificados en cada contratación concreta por los interesados mediante adiciones, tachaduras y cláusulas adecuadas a cada caso. Una regla básica en la materia es que las cláusulas añadidas por las partes al texto impreso del modelo de póliza reflejan más directamente su voluntad, y por ello, deben prevalecer sobre las cláusulas impresas, las añadidas posteriormente. Por lo general se considera que las tachaduras deben ser traducidas e indicar que han sido tachadas en el documento final aceptado por las partes, debido a que, como ya hemos dicho, reflejan los cambios realizados en el documento original y con ello los objetivos perseguidos por los firmantes del contrato." (Del Pozo Triviño and Padín Romero 2005: 818)

12. Socorro Trujillo (2002: 122) compiled information that must be contained in a Charterparty according to the Spanish Code of Commerce.

13. For more information on specific (English-Spanish) terminology on Charterparties, see Bes (1956).

14. See Gabaldón García and Ruiz Soroa (2002: 429-430).

15. "Todo ello conforma una selección de contenidos, una manera de exponer los hechos, una retórica y una percepción del mundo que aparecen plasmados de forma inequívoca en cada realización textual del ámbito jurídico. Si a esta realización textual concreta le sumamos un objetivo comunicativo claro o una función jurídica específica, el resultado es el concepto de 'género jurídico'." (Borja Albi 2007: 144)

\section{REFERENCES}

Aragonés Lumeras, Maite (2009): Estudio descriptivo multilingüe del resumen de patente: aspectos contextuales y retóricos. Bern: Peter Lang.

Bhatia, Vijay Kumar (1993): Analysing Genre: Language Use in Professional Setting. London: Longman.

Bhatia, Vijay Kumar (1997): Applied genre analysis and ESP. In: Tom Miller, ed. Functional Approaches to Written Text: Classroom Applications. English Language Programs: United States Information Agency, 134-149.

BнатіA, Vijay Kumar (2000): Genres in conflict. In: Anna Trosborg, ed. Analysing Professional Genre. Amsterdam/Philadelphia: John Benjamins Publishing Company, 147-162.

Bazerman, Charles (1994): Systems of Genres and the Enactment of Social Intentions. In: Aviva Freedman and Peter Medway, eds. Genre and the New Rhetoric. London: Taylor and Francis, 79-101.

Bes, Jacob (1956): Fletamentos y términos de embarque. $5^{\text {th }}$ ed. (Translated by S. De UrRiarte Y Larraondo) Madrid: Oficina Central Marítima.

Borja Albi, Anabel (2007): Los géneros jurídicos. In: Enrique Alcaraz Varó, ed. Las lenguas profesionales y académicas. Barcelona: Ariel, 141-153.

Borja Albi, Anabel, García Izquierdo, Isabel and Montalt Resurreció, Vicent (2009): Research Methodology in Specialized Genres for Translation Purposes. The Interpreter and Translator Trainer. 3(1):29-46. 
Cuddon, J. A. (1992): The Penguin Dictionary of Literary Terms and Literary Theory. Harmondsworth: Penguin.

Del Pozo Triviño, Maribel (2007): Análisis contrastivo de los géneros del Derecho Marítimo para la traducción (inglés-español). Doctoral thesis, unpublished. Vigo: Universidade de Vigo.

Del Pozo Triviño, Maribel (2011): Analysis Framework for Translation of Maritime Legal Documents. Research in Language. 9(1):95-110. Visited 12 April 2014, <http:versita.metapress.com/content/vh16469631g282v3/fulltext.pdf>.

Del Pozo Triviño, Maribel and Padín Romero, Adela (2005): Conceptos básicos sobre los principales contratos de explotación de buques. In: María Luisa Romana García ed., Actas del II Congreso Internacional AIETI 2005. Formación, investigación y profesión. Madrid: Universidad Pontificia de Comillas, 808-819.

Ezpeleta Piorno, Pilar (2008): El informe técnico. Estudio y definición del género textual. In: Luis Pegenaute, Janet DeCesaris, Mercè Tricás et al., eds. La traducción del futuro: mediación lingüística y cultural en el siglo XXI. Vol. I. Barcelona: PPU.SA, 429-439.

Ferran Larraz, Elena (2010): La regulación legal de la traducción jurídica de documentos de la common law en España: el funcionalismo en términos de "universales" un estándar de equivalencia. Meta. 55(2):266-274.

Gabaldón García, José Luis and Ruiz Soroa, José María (2002): Manual de derecho de la navegación marítima. $2^{\text {nd }}$ ed. Madrid: Marcial Pons. Ediciones Jurídicas y Sociales S.A.

Gamero Pérez, Silvia (2001): La traducción de textos técnicos. Descripción y análisis de textos (alemán-español). Barcelona: Ariel.

Gandía García, Elena (2011): La traducción del género "licencia de software libre": estudio empírico-descriptivo de un corpus paralelo (inglés-español) y repercusiones para su redacción. Doctoral thesis, unpublished. Castellón: Universitat Jaume I.

Hatim, Basil and Mason, Ian (1990): Discourse and the Translator. London: Longman.

Kress, Gunther (1985): Linguistic Processes in Socio-cultural Practice. Victoria: Deakin University Press.

Martin, James R. (1984): Language, register and genre. In: Frances Christie, ed. Children Writing: Reader. Geelong: Deakin University Press, 21-29.

Montalt Resurreció, Vicent, Ezpeleta Piorno, Pilar and García Izquierdo, Isabel (2008): The Acquisition of Translation Competence through Textual Genre. Translation Journal. 12(4):1-12.

Monzó, Ester (2002): La professió del traductor juridic i jurat: descripció sociologica del profesional $i$ anàlisi discursiva del transgènere. Doctoral thesis, unpublished. Castellón: Universitat Jaume I.

Reiss, Katharina and Vermeer, Hans J. (1984): Grundlegung einer allgemeinen Translationstheorie. Tubinga: Niemeyer.

RodríGuez GAYÁn, Eloy Miguel (1999): Los contratos internacionales de fletamento y transporte marítimo. Madrid: Eurolex.

Socorro Trujillo, Karina (2002): La traducción comercial: un modelo didáctico para la traducción de documentos mercantiles del comercio internacional (inglés-español). Doctoral thesis, unpublished. Las Palmas: Universidad de Las Palmas de Gran Canarias.

Swales, John Malcom (1981): Definitions in Science and Law-evidence for Subject-specific Course Component. Fachsprache. 3:106-112.

Swales, John Malcom (1986): Citation analysis and discourse analysis. Applied Linguistics. 7:39-56.

Swales, John Malcom (1990): Genre Analysis. Cambridge: Cambridge University Press.

Wen, Zhisheng (2004): Genre Analysis and Translation of Professional Discourse. US-China Foreign Languages. 13:1-5. 